\title{
Strategic Management Accounting
}

\author{
Mahmoud Lari Dashtbayaz \\ Department of Accounting, mashhad Branch, ferdowsi University, mashhad, Iran \\ Shaban Mohammadi \\ Department of Accounting, mashhad Branch, Islamic Azad University, Quchan, Iran \\ Ali Mohammadi \\ Department of Accounting, mashhad Branch, ferdowsi University, mashhad, Iran
}

\begin{abstract}
The main objective of this paper is to introduce strategic management accounting and strategic management in the world at what stage is the process of moving it How and in what direction it is moving. The reason for this has been done to study the literature and theoretical foundations. Then The following research model for developed countries and Iran and Japan have been used.Content strategy can be Broadly defined as the way an organization. Despite the nearly 30-year history of strategic management accounting, its still not been able to Introduced as an essential element of management accounting. Modern management requires new management accounting aims to help managers Strategic analysis will help to ensure the usefulness of management accounting in the management of the organization, it is necessary accounting Management objectives and strategy in the near term. Traditionally, strategies, future looking, long-term decisions While accounting requires retrospective overview of the company, and to achieve short-term goals planned Is. Strategic management accounting can be defined as "the process of identifying, collecting, selecting and analyzing accounting data for Assist the management team in strategic decision making and organizational effectiveness assessment must be defined. This paper describes the definition and management Strategic Management and its variants and their use for the strategic goals of the organization and management are discussed. Accounting for Management Consolidation of activities in the strategy of the organization should provide information on the three strategic principles of quality, cost and time to help A. Thinking, planning and strategic management of the organization's long-term role in dealing with environmental changes play.
\end{abstract}

Keywords: Accounting management, strategic management, strategic management accounting, strategic principles, developed countries

\section{Introduction}

In today's world of strategic management accounting important Is. Changes in the business environment such as globalization, increasing Competition and focus on customers and the dynamics of the political and social causes The business world. Business survival in today's competitive market about Many accounting administrator. The main purpose of accounting Strategic Management Accounting help the organization to achieve goals It is strategic. The strategy is a way By its position among competitors and distinguishes itself. Achieve its strategic objectives requires that all Flythay Every member of the organization in line with the strategic goals and direction Is. Management accounting is a reflection of past experiences and approaches within Retrospective system, while the focus of Management Accountants Strategic and prospective in vitro system (strategic approach) .lza Strategic management accounting research is necessary so What are the principles? And (SMA) is a strategic management accounting The strategic management accounting in developed countries and Iran At what point is located.

\section{Statement of the problem}

Generally, strategic management accounting theories and issues surrounding The implementation and evaluation of research model is unbelievably diverse in the world In this respect it is of great importance given the parameters and variables Political, economic, social and cultural interoperability issues, thus explaining the In short, it is necessary to follow the above. Management Accounting With its 30-year history as a major strategic era in accountancy Management has not yet found its place. Management Accounting The following are definitions of strategic diversification in some of the Definitions described above.

\section{Definition of strategic management accounting:}

Strategic Management Accounting Management accounting is made up of two words And strategic management that the first word for the measurement and collection Financial information is used by management and discusses the key word Strategic management of all his attention on the value chain and the first person The use of the word Saymvndz Professor (1981), and it follows Express provision, provision and analysis of management 
accounting information About a strategic business unit to business unit and its competitors. According to the enormous efforts of opinions (SMA) first concept Complex integration of content creation strategies in management accounting Is. Defined as follows: provision and (SMA) Brom Analysis of financial market data products and costs Competition and cost structures and maintaining corporate strategy and related matters Competitors in this market in a number of rounds. To create an efficient management accounting systems, understand the strategy of the company, Important. Management accounting systems to corporate strategy Protection, wealth creation, while the system strategy Ignores destroys value. Whenever a strategy to do Company Accounting Management System yen worth of bids run, independent of Yama Support management decisions. In the $80 \mathrm{~s}$, the concept of strategic management accounting in the specialized literature Was debated. In general, management accounting, strategic General approach to accounting for known strategic positioning Is. Nature of Strategic Management Accounting and future external orientation Is thinking. Strategic management accounting can be defined as "the process of identifying, Collecting, selecting and analyzing accounting data to help assess the effectiveness of the management team for strategic and organizational decisions. ., defined (Hoque ,2001). Strategic management accounting is a new phenomenon that has been in Relationship with nature and how to develop it and not have a common vision of Is. Given the importance of reviewing the management accounting system Strategic needs, this article examines the way Strategic management accounting deals. In this approach, the nature of Some of the concepts underlying the analysis and formulation of strategies and activities Strategic review of the main approaches in the development of accounting Strategic management is evaluated. (Kravns and guiding (2001) 14 of strategic management accounting Uncovered:

1. Activity-Based Costing / Management This is a strategic focus on management activities through its Possible measures to achieve a competitive advantage to be defined.

2. Costing features of your products / services as a set of These features are the features that determine the expected cost Consider the product. This technique consists of extra attitude Because the characteristics of the organization's products and services to the attention of the Customer needs are determined.

3. Pattern detection involves identifying best practices and compare the performance of the organization It is a way to improve the company, this approach is based on the orientation Foreign strategic emphasis than competitors.

4. Monitor the competitive position aimed at collecting information about competitors Of sales, market share, volume and unit costs, based on the information Is provided. These techniques enable companies to assess their situation Than major competitors and thus, control or formulate The strategy.

5. Unlike previous methods of assessing the cost of competitors, competing solely on cost evaluation Cost structures focused competitors, the main criticism of this technique for the It is a source of information.

6. Competitor performance appraisal based on public financial statements of sources Public financial statements is to evaluate competitors. Synchronization International Accounting Today permit comparisons between companies in Different countries easier.

7. This technique, customer accounting, customer or group of customers as a single analysis Accounting analysis and to evaluate profit, sales or customer costs and Or customer segments are considered.

8. Means defining a comprehensive performance evaluation system to measure performance Which is integrated with information, both financial and non-financial (assessment Balanced).

9. Life Cycle Costing aimed at calculating the cost of a single Throughout the product lifecycle, from product design to the decline. This Long-term perspective and a market-oriented techniques.

10. Strategic costing process costing systems gradually This means that the management has become a strategic costing systems Should explicitly consider the strategy and long-term competitive advantage.

11. Strategic pricing of information on competitors such as Photo Competitor responses to price changes, price elasticity, resources and experience Focused on the process of pricing.

12. In this method, target costing many external factors involved are.

13. Cost accounting method that provides the value chain All activities from design to product distribution, as well as from This technique represents a strategic implications of economic exploitation and efficiency Derived from foreign communications between companies and suppliers and Customers.

Strategic management capacity that requires such a smart opportunity Is seeking to identify new and emerging opportunities. Hence The ability to think strategically, and then to the Editor Strategic adds. Therefore, management and strategic planning processes Rose Intellectual distinct, but interrelated and complementary to each other in order Hstnd.kh Effective strategic management, maintenance and support. Believes that: Creative and innovative strategies to manage innovative strategies and Innovative strategic management boils still have a way of thinking Analytical and convergent, are operational.

Strategic management accounting approaches:

Teller (1999), to account for the strategic management approach introduces3Out:

Restrictive approach: in the view of management accountingIt is a tool to limit and control strategies. 
This approach, a Before approach control.

Approach: the concept of management accounting tool for Validity of the assumptions underlying the strategy. This approach back attitude before Control strategy is analyzed in terms of the theory of strategy ..... The. In fact, they are the key drivers of success in accounting Management has placed along the value chain.

Approach to development: The concept of accounting management strategy and leadership is one of the fundamental design.

Long Fyld- Smith (2008) in a study to review the information stated The SMA has started since 1980 as it sought Saymvndz Has not been widely used in practice. As Quad 1996), the factors that hinder the acceptance in developed countries Can be expressed this way:

1. Lack of professionals who can features and merits of each The traditional management accounting and strategic play. Hardly provides the information needed for more information They are derived from accounting data.

2. The information obtained from competitors because the estimates are The reality may be different.

3. The information provided is based on speculation and comparability Is difficult.

4. Despite the ease of preparation and analysis of data and save it to the computer Data collection costs may be greater than the benefits.

Data from a management accounting system Strategic performance (triangle T.B.C) The accounting system must have an efficient and effective management of the technical characteristics And behavioral and cultural fit. Indeed, the three key features of business Accounting and management information systems.

\section{Matrix threats, opportunities, strengths and weaknesses of SWOT}

Organizations are working through strategies Wt, St, WO somewhere So that they can use their strategies. Strategy: so Utilization of external opportunities using internal strengths Strategy: Wo improving internal weaknesses to exploit Opportunities St strategies to reduce the effects of existing threats in the external environment Using the strengths of the organization Strategy Wt: Organizations that have used this strategy to the Defensive weaknesses are and aims to reduce domestic and avoid Threats from the external environment.

\section{Four criteria are used to evaluate strategies:}

1. consistency strategy with short-term and long-term objectives and policies And is compatible with human resources. The success of the units That means the failure of another unit or be interpreted in If strategies are incompatible.

2. compatibility with the environment, ie when evaluating strategy, strategy Have a set of procedures to examine. A strategy should The paired response to external and internal decisions that And coordinate with these conditions.

3. feasibility of a strategy should not be too much of a resource Issues and insoluble and should not be used to create and to Viability of the organization providing a range of financial, human and physical Responsible for implementing it successfully.

4. A competitive advantage is usually caused by a superior competitive advantage in the The following three areas: a) sources, b) skills and c) the status of the product.

\section{Why is it difficult to assess the strategies of the past:}

1. The alarming increase in the complexity of environmental factors.

2. More difficult to predict the future and less accuracy in predicting.

3 . Increase the number of variables.

4. Increase the number of competitors .

5. Rapid obsolescence of the best programs 6. Loss of time that can be used to implement the program. (With both Degree of certainty).

\section{Performance is calculated in terms of strategy:}

Should the quantitative and qualitative indicators to assess the performance of strategies Benefit accounting. Is not always possible to evaluate strategies Financial ratios (quantitative indicators) used and strategists Try to compare four types of action: 1. Comparison of the performance of the company in different periods of time.

2. Performance Comparison with competing companies.

3. Comparison of performance with the industry average.

4. Comparison of methods for applying the new accounting strategy.

Assess the effectiveness of the system characteristics for the strategy chosen Management accounting:

1. Effectiveness

2. The cost information is available in size (neither less nor more) 
3.useful information about things over which control or influence

4.picture of the current situation of domestic and Provide an environment.

5. Information to be provided

6. The cooperation of all departments in the process chain analysis Value in strategic management accounting is applicable in this chain The value of all sectors must interact. Thus, cooperation rather than competition It takes. In addition, the participation of all sectors together, the coalition To achieve the strategic objective to achieve a competitive advantage in the short Creates long term.

This phase consists of 5 tools to manage

Cost is strategic:

1. Target Costing (TC)

2. ABC Activity Based Costing

3. Using the Theory of Constraints TOC

4. When JIT production

5. TQM, Tom

\section{Literature}

In this study indicated that the subject Talk of the population and the limited research that has been done Statistical and econometric methods, this study was similar to the other External research study confirms the above mentioned.

\section{Conclusion}

Future performance of companies today are highly dependent on the quality of decisions Effectively be taken by the management and owners Decisions always require information from within and outside the organization. In countries such as America and British interference with economic crisis, governments were too blind to nodes Open economy in the last few years, these statistics do not indicate the Lane Ie where government interference in their economic situation worsens. And unfortunately in our country and with the involvement of both the form And the elimination of competitors from the market and unemployment of productivity and management accounting Strategic industries, particularly industries will bear the high costs The way that the development of strategic management in the industry or not entry Or very slowly during the. If countries such as Japan The continent where we are in terms of language management strategies Europe's economy is even giants. Let's at least a little in economic We will start work on strategic cooperation, economy and away And political tensions. Unfortunately, in our country are faced with the denial phase transition in a way that Senior management and the need to identify the skills or do As a result of the obstinacy and stubbornness do not accept changes to the Use the old strategy and the organizational regulations continues We must pass before this stage. Strategic management accounting To accept the new infrastructure build and the strategies stacked in the paper and Nsazym should immediately abandon research and development of new strategies I use them to learn to be the inventor of the strategy.

\section{References}

[1] P hilip Bromiley Deans professor of Strategic ManagementMerage School of Business, University of California,September 2012.

[2] Susan J Hart,School of Management and Languages,Strategic Management Accounting:, Heriot-Watt University,September 2010.

[3] Robin Roslender, School of Management and Languages,Strategic Management Accounting:,Heriot-Watt University,September 2010.

[4] Chenhall, R.H., Langerfield-Smith, K. (1998) - Therelationship between strategic priorities, managementtechniques and management accounting: an empirical

investigation using a, sy stem approachl, A ccounting, O rganizations and S ociety ,no.23.

[5] Cinquini, L., Tenucci, A. (2007) - Strategic management accounting: exploring distinctive features, and link with strategyll, MP RA paper no.212, disponibil la.

[6] Meier, Kenneth J., O"Toole Jr., Laurence J., Boyne, George A., Walker, Richard M, : Strategic Management, Journal of P ublic Administration Research \& Theory; Jul2007, Vol. 17Issue 3 ,p357-377, Publish: 2007.

[7] P hilip Bromiley Deans professor of Strategic Management Merage School of Business, University of California,September 2012.

[8] www.SYSTEM.parsiblog.com.P aul R. Carlile,School Of Management,University Boston, The

[9].DeYoung,R.,Flannery,M.,Lang,W.,Sorescu,S.,2001.Theinformationcontentofbankexamratingsandsubordinat eddebtprices.JournalofMoney,CreditandBanking 33,900-925.

[10].Diamond,DouglasW.,1984.Financialintermediationanddelegatedmonitoring.ReviewofEconomicStudies51,3 93-414. 
[11]. Nolan, P. Ohina's R se Russia's Fall, Macmillan, 1995.

[12].Pyatt. G.; Roe, A. Social Accounting for Development Planning, CambridgeUniversity Press, 1977.

[13].Pyatt, G.; Round, J. I. Social Accountin 9 Matrices, Symposium Series, Washington D.C.: World

[14].Bank Publications Department, 1985.

[15].Pyatt, G. "Fundamentals of Social Accounting," Economic System Research, 3, 1991,pp. 315 - 41.

[16].Silverman, B.; Yanowitch, M. Winners and Losers on the Russian Road to Capitalism, M. E. Sharpe,1997.

[17].Walder, A. G. China's Transitional Economy, Oxford University Press, 1996. 
The IISTE is a pioneer in the Open-Access hosting service and academic event management. The aim of the firm is Accelerating Global Knowledge Sharing.

More information about the firm can be found on the homepage:

http://www.iiste.org

\section{CALL FOR JOURNAL PAPERS}

There are more than 30 peer-reviewed academic journals hosted under the hosting platform.

Prospective authors of journals can find the submission instruction on the following page: http://www.iiste.org/journals/ All the journals articles are available online to the readers all over the world without financial, legal, or technical barriers other than those inseparable from gaining access to the internet itself. Paper version of the journals is also available upon request of readers and authors.

\section{MORE RESOURCES}

Book publication information: http://www.iiste.org/book/

Academic conference: http://www.iiste.org/conference/upcoming-conferences-call-for-paper/

\section{IISTE Knowledge Sharing Partners}

EBSCO, Index Copernicus, Ulrich's Periodicals Directory, JournalTOCS, PKP Open Archives Harvester, Bielefeld Academic Search Engine, Elektronische Zeitschriftenbibliothek EZB, Open J-Gate, OCLC WorldCat, Universe Digtial Library, NewJour, Google Scholar

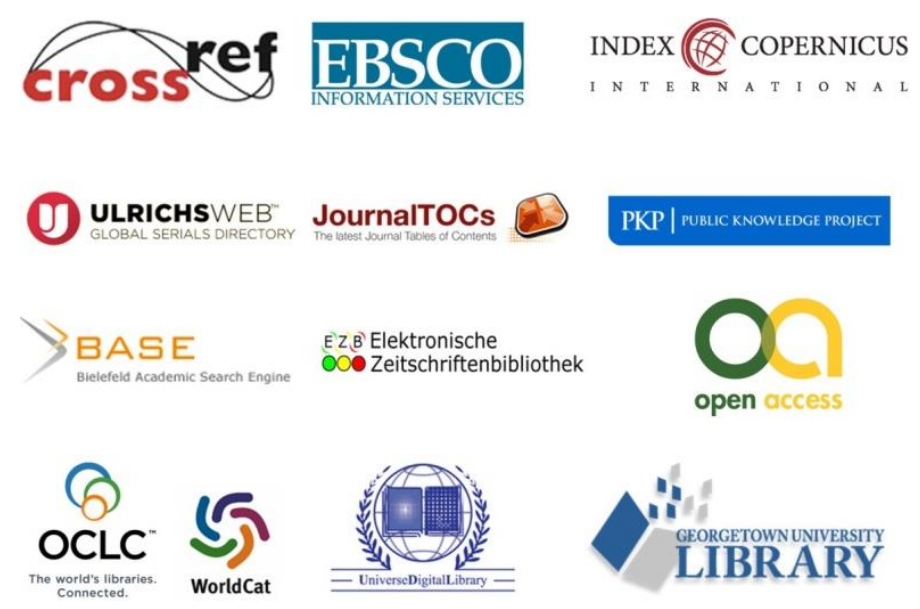

